2016

\title{
Contested Citizenship in Bosnia and Herzegovina
}

Elena Cirkovic

Osgoode Hall Law School of York University, elenacirkovic@osgoode.yorku.ca

Follow this and additional works at: http:// digitalcommons.osgoode.yorku.ca/olsrps

Part of the Civil Rights and Discrimination Commons, and the Transnational Law Commons

\section{Recommended Citation}

Cirkovic, Elena, "Contested Citizenship in Bosnia and Herzegovina" (2016). Osgoode Legal Studies Research Paper Series. 145. http://digitalcommons.osgoode.yorku.ca/olsrps/145 


\title{
OSGOODE HALL LAW SCHOOL \\ LEGAL STUDIES RESEARCH PAPER SERIES
}

Research Paper No. 22

Volume 12, Issue 5, 2016

\section{Contested Citizenship in Bosnia and Herzegovina Routledge Handbook of Global Citizenship Studies, 2014.}

\author{
Elena Cirkovic
}

This paper can be downloaded free of charge from: http://ssrn.com/abstract=2670012

\begin{abstract}
Further information and a collection of publications from the Osgoode Hall Law School Legal Studies Research Paper Series can be found at:

http://www.ssrn.com/link/Osgoode-Hall-LEG.html
\end{abstract}

\section{Editors:}

Editor-in-Chief: Carys J. Craig (Associate Dean of Research \& Institutional Relations and Associate Professor, Osgoode Hall Law School, York University, Toronto)

Production Editor: Kiana Blake (Osgoode Hall Law School, York University, Toronto) 
Osgoode Legal Studies Research Paper No. 22

Vol. 12/ Issue. 5/ (2016)

\title{
Contested Citizenship in Bosnia and Herzegovina
}

Routledge Handbook of Global Citizenship Studies, 2014.

\author{
Elena Cirkovic
}

\begin{abstract}
:
According to Article 15 of the Universal Declaration of Human Rights (UDHR), the right to nationality and citizenship can be considered as a universal human right: '(1) everyone has the right to nationality' and '(2) no one shall be arbitrarily deprived of his nationality nor denied the right to change his nationality'. However, the qualifications of the bearer of 'universal' rights are unspecified. Equating nationality with citizenship has contributed to a situation where people(s) have to fit the category of being a 'national' in order to obtain citizenship. The question of access to national and international rights remains the question of citizenship, and nationality law remains at the core of domestic jurisdiction and state sovereignty. Thus, while the international human rights system and the international community recognize the existence of a universal subject as the bearer of human rights, this recognition is connected to particular concepts of citizenship, statehood, collective identities, and belonging.
\end{abstract}

\section{Author(s):}

Elena Cirkovic

Osgoode Hall Law School

E: elenacirkovic@osgoode.yorku.ca 
„ration policies'. ceived cultural and: University

\title{
Contested citizenship in Bosnia and Herzegovina
}

\author{
Elena Cirkovic
}

According to Article 15 of the Universal Declaration of Human Rights (UDHR), the right to nationality and citizenship can be considered as a universal human right: '(1) everyone has the right to nationality' and '(2) no one shall be arbitrarily deprived of his nationality nor denied the right to change his nationality'. However, the qualifications of the bearer of 'universal' rights are unspecified. Equating nationality with citizenship has contributed to a situation where people(s) have to fit the category of being a 'national' in order to obtain citizenship. The question of access to national and international rights remains the question of citizenship, and nationality law remains at the core of domestic jurisdiction and state sovereignty. Thus, while the international human rights system and the international community recognize the existence of a universal subject as the bearer of human rights, this recognition is connected to particular concepts of citizenship, statehood, collective identities, and belonging.

This chapter analyses the struggles over citizenship in Bosnia and Herzegovina $(\mathrm{BiH})$ following the General Framework Agreement for Peace (GFAP) in $\mathrm{BiH}$ (hereinafter 'the Dayton Peace Agreement'), initialled in Dayton on 21 November 1995 and signed in Paris on 14 December $1995 .{ }^{1}$ The Dayton Peace Agreement ended the $1992-5$ war, which ensued as part of the dissolution of the former Socialist Federal Republic of Yugoslavia (SFRY). As a post-conflict society, the Bosnian case demonstrates the ambiguity of the concept of citizenship both domestically and internationally. The definition of citizenship in $\mathrm{BiH}$ is rooted in the Dayton Constitution, which emerged as part of the GFAP's broader architecture. ${ }^{2}$ However, the Constitution creates a distinction between two categories of citizens on the basis of their ethnicity. This exceptional situation is related to the broader political context in which the peace negotiations took place. More specifically, this chapter refers to the case, Sejdic and Finci v. Bosnia-Herzegovina (hereinafter 'Sejdic and Finci'), ${ }^{3}$ decided in 2009 by the Grand Chamber of the European Court of Human Rights (ECtHR). It is the first case in which the ECtHR applied the general prohibition of discrimination in Protocol No.12 to the European Convention on Human Rights (ECHR).

Bosnian citizenship struggles reveal that the relationship between citizenship and sovereignty is not clearly defined in international human rights law. As critical approaches to international law have observed, citizenship as a political identity relates to the relationship between cultural differences and sovereignty doctrine. ${ }^{4}$ Thus, this chapter positions citizenship within the debates 
over the universality of the subject as a bearer of human rights in international law and argues that this subject is more likely to be qualified by his or her communal affiliation. In other words, some individuals qualify as universal subjects in the international community primarily as citizens of states or as members of a recognized sovereign state, while others see their existence limited as a result either of lack of citizenship (statelessness) or of compromised citizenship (e.g. as a consequence of discriminatory laws and practices enforced by the state). In the case of $\mathrm{BiH}$, the classic form of sovereignty has broken down, ${ }^{5}$ which has resulted in compromised citizenship and capacity of individuals to obtain full recognition as rights-bearing and political subjects (Arendt, 1958).

This chapter consists of two broad sections. The first section provides an analysis of the Sejdic and Finci case. The contradictory aspect of the Dayton Constitution and its embeddedness in ethnic principles, where the Bosnian subject becomes primarily a local ethnic subject and not a universal citizen. The framework of analysis is limited to Bosnia's recent history. The second section briefly discusses the influence of the international community in $\mathrm{BiH}$ and problems of equating the nation with ethnicity and territoriality, especially when the definition of what constitutes a nation is a subject of debate. ${ }^{6}$ The question of what it means to be a citizen, at global, regional, or local levels, relates to the legitimacy of rule and the capacity of human beings to act as political subjects. Historically, the international community has perceived state legitimacy in international law in connection with forms of rule and notions of who is capable of self-rule. Thus, the formation of citizenship in $\mathrm{BiH}$ needs to be viewed in the broader historical context where the international community generates doctrines and political strategies in spaces it views as standing at the margins of, or outside, its borders.

\section{Sejdic and Finci and the institutionalization of discrimination in $\mathrm{BiH}$}

The plaintiffs in Sejdic and Finci, Jacob Finci and Dervo Sejdic, are Jewish and Roma respectively, and citizens of $\mathrm{BiH}$. The applicants complained of their ineligibility to stand for election to the Presidency and the House of Peoples of the Parliamentary Assembly, as stipulated by the Constitution of $\mathrm{BiH}$ and the corresponding provisions of the Election Act 2001, solely on the ground of their ethnic origins. The Constitution and the provisions for internal governing structures of $\mathrm{BiH}$ are part of Annex 4 of the Dayton Peace Agreement. $\mathrm{BiH}$ is divided into three zones, in which one of the three constituent peoples has an absolute majority and other groups are minorities. It is thus a federal/confederal state, which consists of two ethnically defined entities: the mono-national Serbian Republic or Republika Srpska (RS) and the bi-national Federation of Bosnia-Herzegovina (FBIH). The district of Brcko in northeast Bosnia is a selfgoverning body owned by two entities, but placed under the direct sovereignty of the state of Bosnia-Herzegovina.

The Sejdic and Finci decision provides an empirical window into some broader questions about the status of minority rights protection and the relationship between citizenship and sovereignty. It showed clearly that $\mathrm{BiH}$ needed a constitutional reform. When $\mathrm{Mr}$. Finci informed the Central Election Commission of his intentions to stand for election to the Presidency and the House of Peoples of the Parliamentary Assembly, he received written confirmation from the Central Election Commission that he was ineligible to stand for such elections because of his Jewish origin. The Council of Europe has thus stressed the need for changes to the electoral procedures, since they are in conflict with the ECHR. For the reforms to be successful, various discriminatory elements would need to be abolished, in particular as they relate to the political rights of different groups of the Bosnian population. 
The most striking characteristic of the Dayton Constitution is that it was de facto adopted during peace negotiations. As such it is a part of an international treaty. On the one hand, the Bosnian Constitution enshrines democracy despite the lack of democratic participation at its very origin. Article 1(2) states that Bosnia and Herzegovina shall be a democratic state, which shall operate under the rule of law and with free and democratic elections. Article 11(1) states that $\mathrm{BiH}$ and both Entities shall ensure the highest level of internationally recognized human rights and fundamental freedoms. The Constitution provides that certain rights and fundamental freedoms shall have priority over all other law and that an amendment may not affect these rights adversely. The Parliament of $\mathrm{BiH}$ can amend the Constitution.

The Preamble of the Constitution of $\mathrm{BiH}$ states that "constituent peoples are the adopters of the Constitution of $\mathrm{BiH}$, i.e. Bosniacs, Croats, and Serbs, as constituent peoples (along with Others), and citizens of Bosnia and Herzegovina'. The Constitution does not define the 'Others', but it also does not refer to an abstract citizen without ethnic identification. Under Article V, the Presidency of Bosnia and Herzegovina consists of three Members: one Bosniac and one Croat, each directly elected from the territory of the FBIH, and one Serb directly elected from the territory of the RS. Similarly, Article IV.1 relating to the composition of the second chamber of parliament, the House of Peoples, indicates that five Croats and five Bosniacs are to be chosen as Delegates of the FBIH by the Bosnian and Croat Delegates to the House of Peoples of the Federation, while the five Serbian Delegates of the RS are to be chosen by the National Assembly of the Republic. Nine members of the House of Peoples shall comprise a quorum, provided that at least three Bosniac, three Croat, and three Serb Delegates are present. As stipulated in Article IV.3, all legislation shall require the approval of both chambers. The Delegates and Members shall make their best efforts to see that the majority includes at least one-third of the votes of Delegates or Members from the territory of each Entity.

The Bosnian Constitution is based on the authority of the Dayton Peace Agreement, as well as the decisions of the Constitutional Court of $\mathrm{BiH}$. Importantly, the 2000 Constituent Peoples' Decision of the BiH Constitutional $\mathrm{Court}^{7}$ has redefined the principle of constituency of peoples in the sense that now there are three constituent ethnic groups in the entire territory of $\mathrm{BiH}$. Four partial Decisions of 2000 related to specific provisions of the Constitutions of the Entities of Bosnia and Herzegovina, which have been found to be in contravention of the 1995 Constitution of Bosnia and Herzegovina. Thus the Constitutional Court derived from the constitution the normative principle of multi-ethnicity challenging institutional segregation and national homogenization within the State institutions. Further, it emphasized the principle of collective equality of constituent peoples and the equality of the collective ethnic representation of the three constituent peoples. And finally, the Constitutional Court stressed that the rule regarding the prohibition of discrimination included the prohibition of de jure discrimination, the prohibition of de facto discrimination, and the prohibition of past de jure discrimination (Banovic and Gavric, 2011, pp. 7-9). Because of persisting political obstacles to the implementation of the decision, it was referred to the Office of the High Representative (OHR), which resulted in the 2002 Decision Amending the Constitution of the Federation of Bosnia and Herzegovina. ${ }^{8}$ The consequent reorganization of all entity institutions also introduced mandatory quotas of representation in all parts of government for all three constituent ethnic groups and for the 'Others' in both entities. However, as has been noted above, the House of Peoples and the Parliamentary Assembly (the second chamber) and the Presidency are composed only of persons belonging to the three constituent peoples. Furthermore, the Constitutional Court could not make an impact at the state level and the recognition of the political rights of 'Others' could only be resolved through the ECtHR as a supranational remedy. 
In the Sejdic and Finci decision, the ECtHR found that the applicants' continued ineligibility for election to the Presidency of $\mathrm{BiH}$, because they were not affiliated with a 'constituent people' as required by the Constitution, lacked an objective and reasonable justification and violated Article 1 of Protocol No. 12 to the ECHR (para. 50). It concluded that discrimination on the ground of ethnicity was prohibited, inter alia, by ECHR Article $14^{9}$ in conjunction with Article 3 of Protocol No. $15 .^{10}$ The ruling of the ECtHR has not yet been implemented in $\mathrm{BiH}$, as more substantial efforts and political will are needed to reach a solution. The ECtHR emphasized that where a difference in treatment is based on race or ethnicity, the notion of objective and reasonable justification must be interpreted as strictly as possible, as no difference in treatment which is based exclusively or to a decisive extent on a person's ethnic origin can be objectively justified in a contemporary democratic society built on the principles of pluralism and respect for different cultures (para. 44). Nevertheless, the ECtHR stated that Article 14 does not prohibit Contracting Parties from treating groups differently in order to correct 'factual inequalities' between them. In certain circumstances, a failure to attempt to correct inequality through different treatment may, without an objective and reasonable justification, give rise to a breach of that Article.

The Bosnian Constitution allocates protection to collective rights above individual rights. It is a type of 'ethnic democracy', which only recognizes as democratic participants leaders of the main ethno-nationalist parties (Mujkic, 2007, p. 116). The Dayton Peace Agreement and the Constitution thus arguably construct second-class citizens in $\mathrm{BiH}$ who are excluded from the community and its laws as equal participants. Since the current Constitution is part of a peace treaty, it was drafted and adopted without the application of procedures which could have provided democratic legitimacy. As the ECtHR ruling notes, it is a unique case, because it was never officially published in the official languages of the country concerned but was agreed to and published in English (para. 6).

The ECtHR evaluated the discriminatory nature of the Bosnian Constitution in the context of conflict and whether the preservation of peace in Bosnia served as a legitimate aim for differential treatment. The exclusion rule pursued 'at least one aim which is broadly compatible with the general objectives of the Convention ... namely the restoration of peace'. The provisions were designed to end brutal conflict marked by genocide and 'ethnic cleansing'. The ECtHR thus correlated the nature of the conflict directly with the need to approve 'constituent peoples' and ensure peace. While it does not justify the exclusion of other communities in Bosnia's peace process, it explains the 'preoccupation with effective equality between the 'constituent peoples' in the post-conflict society' (para. 45).

After the ECtHR indicated that it did not have competency to decide whether the preservation of peace constituted a legitimate aim (para.46), it proceeded to evaluate Bosnia's capacity to promote positive reforms in areas of human rights and democratization and in compliance with the ECHR and the Council of Europe post-accession commitments (paras. 55-6). This, however, implies that the responsibilities rest with the Bosnian state, despite international involvement in the process of signing the peace accords, as well as the establishment of its institutions and forms of governance.

The judgement stands in accord with general international law and instruments developed against ethnic discrimination. However, the ECtHR remained ambiguous in its conclusion on the legacy of this initial compromise. The majority ruling concluded that the constitutional provisions in $\mathrm{BiH}$ were not intended to establish ethnic domination, as was argued by the applicants, but to end the conflict. The achievement of peace required measures which would secure effective equality between the warring parties, which came to be defined as the 'constituent peoples'. 


\section{Collective vs. the individual and citizenship in Bosnia and Herzegovina}

The modern Bosnian state has its origins in 1943, as it became one of six constituent federal units of the former Socialist Federal Republic of Yugoslavia (SFRY). However, it was distinct from other Yugoslav republics, in that none of the three main ethnic groups (Muslims (Bosniaks), Serbs, and Croats) had a majority. Citizenship in the SFRY consisted of republican and federal levels of citizenship. Except for $\mathrm{BiH}$, republics were formed around one ethnic identity. Thus, after the dissolution of SFRY in 1991-2, creating a unitary state in $\mathrm{BiH}$ was difficult. ${ }^{11}$ This difficulty, however, is not very different from the secession of other republics from the former Yugoslavia. External self-determination of $\mathrm{BiH}$ presupposed the realization of the collective right to territoriality, formation of the classic nation-state, and internationally recognized sovereignty. Because of the plurality of ethnic and nationalist claims, $\mathrm{BiH}$ became a consociational state, with power-sharing institutions and ethno-territorial confederalism, which reflected the interests of the ethno-political elites among BiH's constituent peoples (Mujkic et al. 2008, p. 2).

The root causes and process of the partitioning of the SFRY and the eventual cantonization of $\mathrm{BiH}$ have been extensively discussed elsewhere. ${ }^{12}$ The dissolution of the SFRY was aided by two processes: first the internal self-determination expressed through elections, and secondly, the international community's recognition of the newly declared preferences for external self-determination of each republic along ethnic-nationalist lines. The internal right to self-determination is here defined as the ability of peoples to participate fully within the overall national polity. This includes full participation within the legal system and, in general, having full political, cultural, and civil rights. External self-determination is the collective right of peoples to sovereignty and international recognition of that people.

As Crawford (2007) argues, the emergence of many new states represents one of the major political developments of the twentieth and twenty-first centuries. While it has changed the character of international law and the practice of international organizations, it has been one of the more important sources of international conflict (ibid., p. 4). But significant for the formation of citizenship in those newly found states is the fact that this development did not entail that it be regulated by some universal norms of international law in general and human rights law in particular. For example, the argument that the formation of a new state is a 'matter of fact and not of law', that is, the theory that statehood is legal independently of recognition, emphasizes the criterion of effectiveness, not legitimacy. ${ }^{13}$ However, the constitutive theory claiming that the rights and duties pertaining to statehood derive from recognition by other states similarly relies on discretionary decision-making, which implies the absence of some specific regulation or 'right to statehood'. Both assume primacy of politics over a legal principle. Crawford further points out that the constitutive theory incorrectly identifies state formation with diplomatic recognition and consequently 'fails to consider the possibility that identification of new subjects may be achieved in accordance with general rules or principles rather than on an ad hoc, discretionary basis' (ibid., p. 5).And more importantly, where do we find the situations of 'fact' and where 'law'?

The political background of state formation 'in fact' has implications not only for the legitimacy of its existence within the international community, but also for the legitimacy of its institutions. In the case of $\mathrm{BiH}$, the post-war institutions were formed in a political climate which centred on the necessity of ending a war and ensuring regional peace and stability. Fundamentally, the question then is whether there is an identifiable, coherent, or complete system of law at the international level which could be relevant in such situations, and the scope and content of principles which provide human rights protection for individuals. Crawford, for instance, insists 
that there is a formally complete system of law especially with respect to the use of force and nationality, which are fields closely related to the existence and legitimacy of states (2007, p. 6).

The international community recognized claims to secession from the SFRY of each former republic. However, the emergent states did not adopt civic democracy; rather, the elections confirmed the conflict between, on one hand, the citizens' civic or republican identity and, on the other, ethnic belonging. The reasons for this are rooted in the politics of the inter-republican and inter-ethnic quarrels after the dissolution of the League of Communists of Yugoslavia at its 14th Congress in January $1990 .{ }^{14}$ Each republic organized separately their first free democratic elections, which saw the emergence of ethnic-nationalist parties. Two political identities - ethnic and civic - could now be reconciled only if a citizen resided in his or her own ethnic republic and therefore belonged to its ethnic majority (e.g. Serbia and Croatia). However, this was not the case in $\mathrm{BiH}$ because of its multi-ethnic composition. After the dissolution of the SFRY the considerable number of individuals who lived outside the new nation-states defined by their ethnic groups were now living inside republics to which they had historically belonged civically, as republican citizens and citizens of the SFRY. The attempt to create homogenous territories during the 1992-5 war included 'ethnic cleansing', as well as other gross and systematic human rights violations such as genocide. The ethno-national conception of citizenship finally prevailed and fuelled violent conflicts over the redefinition of national borders within which the ethno-national states were to be formed on the basis of the absolute majorities of the core ethno-national groups.

In $\mathrm{BiH}$, equating ethnicity with nationality and nationality with sovereignty resulted in what Asim Mujkic has referred as an 'Ethnopolis', a state where '[under] the cover of the legitimacy conferred by free and fair elections, citizens as individuals are stripped of any political power' $(2007$, p. 116). The recognized communities in $\mathrm{BiH}$ presuppose a pre-political bond of ethnicity and religion among a category of people. A 'people' is defined in terms of its blood origin, its heritage, and its traditions, or as an imagined community of membership and affiliations (Fichte, 1922; Anderson, 2006). Ethnopolitics, at least in the case of $\mathrm{BiH}$, is a political set-up in which a person's citizenship is predetermined by his or her kinship and belonging to a group of imagined common origin. Mujkic relates ethnopolitics to a crisis and a permanent condition of a threat; in other words, a constant appeal to the existential danger faced by the particular ethnic group (2007, p. 119).

\section{International community and the definition of citizenship in $\mathrm{BiH}$}

In evaluating the nature of Bosnian citizenship it is significant to consider the influence of the international community. The Bosnian Constitution emerged as part of the Dayton Peace Accords without the approval of the domestic legislature. It went into effect upon signature of the GFAR by the Republic of Bosnia and Herzegovina, the Republic of Croatia and the Federal Republic of Yugoslavia. The signature of the peace agreements was witnessed by the Presidents or Prime Ministers of the United States, the Russian Federation, the Federal Republic of Germany, the United Kingdom, France, and by the European Union (EU) Special Negotiator. Significantly, in his dissenting opinion in Sejdic and Finci, Judge Giovanni Bonello demonstrated a particular approach to $\mathrm{BiH}$ as a location where exceptional measures are necessary to keep the country together. The judge condemned the court's ruling and pointed out the dangers of challenging the status quo:'I do not identify with this. I cannot endorse a Court that sows ideals and harvests massacre'. What prompted such a conclusion was his concern that the ECtHR decision presented 'a clear and present danger of destabilizing the national equilibrium' (para. 56). What the 
facts of the case reveal, however, is the ambiguity not only in what constitutes a 'national equilibrium', but also in what we can expect from supranational human rights regimes in relation to other global, regional, and local priorities.

Judge Bonello's position can be explained by the international community's foreign policy, which, from the onset of the crisis in the SFRY, adyocated preserving a vague conception of 'stability' or 'peace' rather than an insistence on democratization and human rights. In short, the $\mathrm{BiH}$ became what Amin Maalouf has described as a structure where 'an individual's place in society is dependent on his belonging to some community or another' perpetuating 'a perverse state of affairs that can only deepen division' (Maalouf, 2003). Judge Bonello argued that in its adjudication over the discriminatory aspects of the constitution, the ECtHR had 'canonized' the relevant ECHR rights, while discounting the values of peace and reconciliation. These values were, 'at least' equally invaluable. What, however, are those values? In the Bosnian context, those values include discrimination against various members of the Bosnian polis, who became defined as the 'Others' in the post-war period. While the argument provided in this opinion is rather spirited, it also divulges the particular mindset of the international community which brought the DPA into being.

The Bosnian case presents us with the problem of a situation where the local-global relationship of norm application somehow loses its purpose because of specifics of local and global politics. Judge Bonello asks: 'Does it fall within this Court's remit to behave as the uninvited guest in peace-keeping multilateral exercises and treaties that have already been signed, ratified and executed?' The rest of his opinion refers to the architects of the Dayton Peace Agreement as peace-devising do-gooders and the action of the EU and of the United States of America as 'fathering' the Accords. He argues that human rights concerns have little place in 'exceptionally perverse situations in which the enforcement of human rights could be the trigger for war rather than the conveyor of peace'(para. 53).

The differing opinion of Judge Ljiljana Mijovic, however, brings to the fore some of the more fundamental questions, which were missing in the ECtHR ruling. The tripartite structure of $\mathrm{BiH}$ is a result of the political compromise achieved by the Dayton Peace Agreement. She argues: 'In my opinion, the key question that required an answer in this case is whether that tripartite structure was ever justified, and whether it continues to be justified' (para. 43). Moreover, the Bosnian Constitutional Court has already addressed the matter of electoral discrimination in three separate cases. ${ }^{15}$ In each case the Court found that the Constitutional structure was reasonably justified in the exceptional context of post-conflict Bosnia. At the domestic level, the national courts have adopted a self-image of exceptionality because of the constitutional constraints.

The decision that $\mathrm{BiH}$ was an exceptional case, which also accorded diminished status to Bosnia's minorities, was an international as well as a local decision. But this decision did not recognize Bosnian citizens as responsible subjects. The challenge in Sejdic and Finci is formulated in response to a particular situation in $\mathrm{BiH}$, which is exceptional not only because of the legacy of armed conflict, but also because of particular perceptions of the region on the part of international commuity, as has been most clearly expressed in Judge Bonello's dissent.

States enjoy a certain margin of appreciation in assessing whether and to what extent the differences in otherwise similar situations justify a different treatment in law, but the ECtHR gives the final ruling in this respect. The margin of appreciation contradicts the concept of universal human rights protection and conditions citizenship on the basis of a form of belonging. However, in the case of $\mathrm{BiH}$ this is not so clear, because $\mathrm{BiH}$ does not have the qualities of a fully independent state with reference to general criteria of international law, which define such status (Brownlie, 2008). ${ }^{16} \mathrm{BiH}$ is an independent state by virtue of being part of the UN, having 
been a rotating member of the Security Council, and having its territorial integrity recognized by its neighbours. However, it remains formally under the protectorate status of the international community. The ruling is thus ambiguous in relation to the role of the international community not only during the signing of the Dayton Peace Accords, but also in the post-conflict period.

Importantly, Annex 10 of the Dayton Peace Agreement, 'Agreement on civilian implementation of the peace', created the office of the High Representative (HiRep). As Article I stipulated, the HiRep was appointed 'to facilitate the Parties' own efforts and to mobilize and, as appropriate, coordinate the activities of the organizations and agencies involved in the civilian aspects of the peace settlement by carrying out, as entrusted by a U.N. Security Council resolution'. The Peace Implementation Council (PIC) was established for BiH in 1995 as an ad hoc group of 55 countries and organizations, in order to sponsor and direct the peace implementation process. The Steering Board of the PIC nominates and funds the position of the HiRep. Additionally, the Security Council acts as a supreme guardian of peace and order in the country. The HiRep is also the final authority in interpreting the Dayton Peace Agreement on the civilian implementation of the peace settlement (art. 5). In addition, the parties to the Dayton Peace Agreement provided that military implementation of the agreement was to be overseen by an Implementation Force (or the Stabilization Force). The Organization for Security and Cooperation in Europe (OSCE) was to supervise the conduct of democratic elections, the President of the ECtHR was to select three members of the Constitutional Court, and the International Monetary Fund (IMF) was to appoint the Governor of the Central Bank. The extensive international involvement in the domestic affairs of $\mathrm{BiH}$ arguably problematizes its political capacity to reform its institutions, including the Constitution.

The position of $\mathrm{BiH}$ in the eyes of the international community becomes even more complicated in its post-war relationship with the EU (Brljavac, 2012). The process of Europeanization is seen as the influence and impact of the EU on the domestic political, legal, and economic structures of the countries aspiring to EU membership (Radaeilli, 2004). In the aftermath of the war, the EU implemented various programmes in relation to the states emerging out of former SFRY which would allow them to move closer to EU membership. In 1999, BiH and other former Yugoslav countries entered the Stabilization and Association Process (SAP). The main objective of the SAP has been to strengthen a democratic transition of the countries in the region, with the implementation of substantial political, legal, and economic reforms. In 2008, $\mathrm{BiH}$ also signed and ratified the Stabilization and Association Agreement (SAA) with the EU and accepted amending electoral legislation regarding members of the $\mathrm{BiH}$ Presidency and House of Peoples delegates to ensure full compliance with the ECHR and its postaccession commitments to the Council of Europe. ${ }^{17}$ The ECtHR and the EU demanded constitutional reforms as part of the need for advancement in 'ascension' talks with the EU. The ECtHR ruling demonstrates that in theory, we have established anti-discrimination provisions. Simultaneously, those provisions depend on international and local politics and the will of states to enforce them.

\section{Creating local identities}

While individuals have a degree of capacity to act and claim their rights beyond state borders, citizenship and human rights protection still depend on membership of a community, as well as statehood. In other words, it also matters which state provides the citizenship. This influences the existence of the individual not only as member of that particular community, but how the individual can enter the supranational realm. The so-called 'Balkan' region has been allocated to the realm of exception rather than the norm. Hence, categories of citizenship have been 
conditioned by both local self-images and international perspectives on the region. ${ }^{18}$ Taking Edward Said's 'orientalist' thesis presented in Orientalism: Western conceptions of the Orient (1978) as a starting point, this chapter considers the manner in which the 'Orient' or in this case the 'Balkans' have been imagined by the international community as a zone wherein the dictates of international law have been, in some instances, interpreted arbitrarily and applied selectively. In such a framework, the local citizenship loses its universality and becomes allocated to local ethnic particularity.

Claims forwarded in Sejdic and Finci can be read as claims to recognition of human rights not only of individuals from particular communities, but individuals who can claim them on the basis of their universal citizenship. Sejdic and Finci is an appropriation of the external gaze towards $\mathrm{BiH}$, which prevailed during the Dayton Peace Accords. The claimants insisted on being recognized as free and equal citizens, not just as members of a particular ethnicity. Significantly, the Bosnian case cuts through the more general debates on constitutionalism and pluralism, because it reminds us of the persisting differentiation between types of peoples and their capacity to fall within the borders of the 'international community'. ${ }^{19}$

The current Bosnian dilemma over its post-war transitional process and possible accession to the EU accentuates the tensions in the global and local perceptions of the region. The relationship of $\mathrm{BiH}$ to the rest of the world is not that of an independent sovereign state, but a state largely designed through internationally brokered peace accords, continuous foreign presence in its governing institutions, and a constitutional crisis. The Bosnian Constitution creates new Bosnian identities without the democratic participation of local peoples. It also counters paradoxically the desired transition towards the EU because its discriminatory nature institutionalizes the Bosnian crisis. Meanwhile, the Bosnian citizen reflects a particular image of the ethnic identity of the place: the imagined and ethnicized $\mathrm{Balkans}$. $\mathrm{BiH}$ then becomes a location where everyone is different, because they presumably choose to live primarily in accordance with their respective religions and ethnicities.

\section{Conclusion}

$\mathrm{BiH}$ has historically been a site of overlapping identities and contemporary governing, and legal structures would have to reflect such multiplicity without ethno-cultural domination. However, there is no recognition of a 'citizen' in $\mathrm{BiH}$ without an accompanying ethnic identity. Such an identity determines the type and quality of citizenship, which constitutes a discriminatory practice and stands in direct opposition to global developments in human rights protection and democratic citizenship. This is possible because the case of $\mathrm{BiH}$ has been treated by the international community as an exception, where international peace and security had to be prioritized over potential human rights claims. Bosnian citizenship became a position outside the more universal concept of a political citizen unencumbered by a static position of his or her local identity.

Individual subjects, who in the Sejdic and Finci case are two citizens of $\mathrm{BiH}$, observe the ECtHR as a body which is supposed to uphold a set of principles which they would like to see as applicable to their individual lives. This aspiration was called into question, not only by the dissenting opinions of the ECtHR decision and the political stalemate in $\mathrm{BiH}$, but by a general perspective on their inherent capacities to live as equal citizens. In its partitioned and dependent situation, post-conflict $\mathrm{BiH}$ is in a situation of instability where hope for emergency provisions stunts the democratization deemed necessary to prevent any future conflict. The ECtHR enters into the framework created by that judgement and attempts to apply human rights norms regarding discrimination. 


\section{Notes}

1 General Framework Agreement for Peace in Bosnia and Herzegovina, Dec. 14, 1995, Bosn. \& Herz.Croat.-Yugo., 35 ILM 75 (1996).

2 Annex 4 of the GFAP sets out the Constitution of Bosnia and Herzegovina,Articles IV andV of which define the eligibility for the House of Peoples and the Presidency.

3 Sejdic and Finci v. Bosnia and Herzegovina, Application nos. 27996/06 and 34836/06, Council of Europe: European Court of Human Rights, 22 December 2009. Available online at www.unhcr.org/refworld/ docid/4b44a28a2.html (accessed 20 March 2013).

4 Anghie 1996, p. 231; Orford 2009, p. 981. On the relationship between citizenship and Orientalism see Isin 2012b, pp. 563-72. See also Isin 2012a, pp. 450-467 and Isin 2011, pp. $209-29$.

5 For classic definitions of sovereignty see, Crawford 2007; Brownlie 2008.

6 Balibar 2003.

7 The Decision of the Constitutional Court on the Constituency of Peoples, No. U 5/98-III. Four partial Decisions of the Constitutional Court of Bosnia and Herzegovina in this are: Constitutional Court Decision of 28, 29 and 30 January 2000 (Official Gazette of Bosnia and Herzegovina, no 11/00 of 17 April 2000), of 18 and 19 February 2000 (Official Gazette of Bosnia and Herzegovina, no. 17/00 of 30 June 2000), of 30 June and 1 July 2000 (Official Gazette of Bosnia and Herzegovina no. 23/00 of 14 September 2000) and of 18 and 19 August 2000 (Official Gazette of Bosnia and Herzegovina, no. $36 / 00$ of 31 December 2000).

8 Decision Amending the Constitution of the Federation of Bosnia and Herzegovina, 7/10/2002.

9 Article 14 states:'The enjoyment of the rights and freedoms set forth in this Convention shall be secured without discrimination on any ground such as sex, race, colour, language, religion, political or other opinion, national or social origin, association with a national minority, property, birth or other status.'

10 Article 3 states: 'The High Contracting Parties undertake to hold free elections at reasonable intervals by secret ballot, under conditions which will ensure the free expression of the opinion of the people in the choice of the legislature.'

11 Pellet 1992, pp. 178-85.

12 Gagnon 2004.

13 On this perspective see, Oppenheim 1905, p. 264. Also, Foreign Minister Eban (Israel), arguing against a request for an advisory opinion of the International Court on the status of Palestine: SCOR 340th mtg, 27 July $1948,29-30$.

14 Stiks 2011.

15 Case No. U-5/04, Admissibility, para. 13 (Const. Ct. Bosn. \& Herz. Mar. 31, 2006); Case No. U-13/05, Admissibility (Const. Ct. Bosn. \& Herz. May 26, 2006); Case No. AP-2678/06, Adnissibility \& Merits (Const. Ct. Bosn. \& Herz. Sept. 29, 2006). The decisions of the Constitutional Court are available at www.ccbh.ba/eng/odluke/ (accessed 25 July 2012).

16 From a legal perspective, Ian Brownlie indicated that the principal corollaries of the sovereignty and equality of states are: 1) a jurisdiction, prima facie exclusive, over a territory and the permanent population living there; 2) a duty of non-intervention in the area of exclusive jurisdiction of other states; and 3) the dependence of obligations arising from customary law and treaties on the consent of the obligator (Brownlie 1990, p. 287).

17 Documents and reports on Bosnia and Herzegovina's relations with the EU are available on the European Commission website: www.ec.europa.eu (accessed 25 July 2012)

18 Campbell 1999, p. 395; see also Stiks 2006, pp. 483-500; Stahn 2008.

19 Anghie 2004.

\section{References}

Anderson, B. 2006. Imagined communities: reflections on the origin and spread of hationalism. 2nd ed. London:Verso.

Anghie, A. 1996. 'Francisco de Vitoria and the colonial origins of international law'. Social and Legal Studies 5: 321-36

Anghie, A. 2004. Imperialism, sovereignty, and the making of international law. Cambridge: Cambridge University Press.

Arendt, H. 1958. The origins of totalitarianism. New York: Meridian Books.

Bakic-Hayden, M. 1995 'Nesting orientalisms: the case of Former Yugoslavia'. Slavic Review 54: 917-31. 
sn. \& Herz.

$\mathrm{dV}$ of which

il of Europe

$\mathrm{rg} / \mathrm{refworld} /$

Orientalism

Four partial ional Court $11 / 00$ of 17 10. $17 / 00$ of 10. $23 / 00$ of regovina, no.

2002.

11 be secured cal or other ler status.'

ble intervals he people in

uing against COR 340th

o. U-13/05, ty \& Merits available at

sovereignty permanen on of other : consent of te European

idon:Verso egal Studies
Balibar, E. 2003. We, the people of Europe? Reflections on transmational citizenship. Princeton, NJ: Princeton University Press.

Banovic, D. and Gavric, S. 2011. 'The Constitutional Court of Bosnia and Herzegovina and its role in the process of democratization of the post-war political system of Bosnia and Herzegovina'. Berlin Graduate School of Social Sciences Workshop, Advocates or Notaries of Democracy? A Comparative Socio-legal Analysis of the Role of Constitutional Courts in Political Transformation Processes, September 22, 2011.

Brljavac, B. 2012. 'Assessing the European criteria in Bosnia and Herzegovina: a litmus test for the European Union'. Joumal of Comparative Politics 5 (1), p. 4.

Brownlie, I. 2008. Principles of public international law. Oxford: Oxford University Press.

Buchanan, A. 2000. Rawls's law of peoples: rules for a vanished Westphalian world. Ethics 110, pp. 697-721.

Campbell, D., 1999. 'Apartheid cartography: the political anthropology and spatial effects of international diplomacy in Bosnia'. Political Geography 18 p. 395.

Chandler, D. 2000. 'Bosnia: prototype of a NATO Protectorate, in T. Ali (ed.) Masters of the universe? NATO's Balkan crusade. London and New York:Verso Books. pp. 271-272.

Crawford, J. R. 2007. The creation of states in international law. Oxford: Oxford University Press.

Fichte, J. D. 1922. Addresses to the German nation. Translated from German by R.F. Jones and G.H. Turnbull. Chicago: The Court Publishing.

Gagnon,V. P. 2004. The myth of ethwic war: Serbia and Croatia in the 1990s. Ithaca, NY: Cornell University Press.

Goldsworthy, V. 1997. Black lamb and grey falcon: Rebecca West's journey through the Balkans. Women: A Cultural Review, 8 (1), pp. 1-11.

Habermas, J. 2001. The postnational constellation: political essays. Cambridge, MA: MIT Press.

Isin, E. F. 2011. 'Ottoman waqfs as acts of citizenship', in P. Gazaleh (ed.), Held in trust: waqf in the Muslim world. Cairo: American University in Cairo Press. pp. 209-29.

Isin, E. F. 2012a. 'Citizens without nations'. Environment and Planning D: Society and Space 30 (1), pp. $450-67$.

Isin, E. F. 2012b. 'Citizenship after orientalism: an unfinished project'. Citizenship Studies 16 (5-6), pp. 563-72.

Maalouf, A. 2003. In the name of identity: violence and the need to belong. New York: Arcade Publishing.

Mujkic, A. 2007. 'We, the citizens of Ethnopolis'. Constellations 14 (1), pp. 112-28.

Mujkic, A., Seizovic, Z., and Abazovic, D. 2008. Country specific report: Bosnia and Herzegovina: the role of human and minority rights in the process of reconstruction and reconciliation for state and nation-building: Bosnia and Herzegovina. MIRICO: Human and Minority Rights in the Life Cycle of Ethnic Conflicts.

Office of High Representative (1995) 'The general framework of agreement: Annex 4: the Bosnian Constitution' 14 December 1995. Available online at www.ohr.int/dpa/default.asp?content_id=372. (accessed 15 July 2012)

Oppenheim, L. F. L. 1905. International law, vol. 1, 1st ed. London and New York: Longmans, Green and Co.

Orford, A. 2009. 'Jurisdiction without territory: from the Holy Roman Empire to the responsibility to protect'. Michigan Journal of International Law 30, p. 981.

Pellet, A. 1992. 'The opinions of the Badinter arbitration committee: a second breath for the self-determination of peoples'. European Journal of International Law 3 (1), pp. 178-85.

Radaeilli, C. 2004. 'Europeanisation: solution or problem?' European Integration onlinePapers (EioP) 8 Available online at http://eiop.or.at/eiop/texte/2004-016a.htm (accessed 28 July 2012)

Rawls, J. 2001. The law of peoples: with 'the idea of public reason revisited'. Cambridge, MA: Harvard University Press.

Said, E. 1978. Orientalism: Western conceptions of the Orient. London: Routledge.

Sejdic and Finci v. Bosnia and Herzegovina 2009 (application nos. 27996/06 and 34836/06) Council of Europe: European Court of Human Rights, 22 December 2009. Available online at www.unhcr.org/ refworld/docid/4b44a28a2.html (accessed 20 March 2013)

Stahn, C. 2008. The law and practice of intemational territorial administration. Versailles to Iraq and beyond. Cambridge: Cambridge University Press.

Stiks, I. 2006. 'Nationality and citizenship in the Former Yugoslavia: from disintegration to European integration'. Southeast European and Black Sea Studies 6 (4), 483-500.

Stiks, I. 2011. 'Being citizen the Bosnian way': transformations of citizenship and political identities in Bosnia-Herzegovina', in: F. Cheneval and S. Ramel (eds.), Transitions: from peace to shared political identities: exploring pathways in contemporary Bosnia-Herzegovina. Université de Genève Institut Européen 51 (1-2).

Todorova, M. 1997. Imagining the Balkans. New York: Oxford University Press. 